\title{
大気污染と感染の小児気道系病変
}

\author{
吉 田

\section{Air Pollution and Respiratory Infection in Childhood} \\ Yutaka Yoshida \\ Department of Pediatrics Nippon Medical School, Tokyo Japan
}

豊

1) The correlation between air pollution and respiratory diseases in childhood, especially bronchial asthma, asthmatic bronchitis and chronic bronchitis were investigated. The frequency of the asthmatic bronchitis and bronchitis in air polluted area were increased significantly.

2) As to the pulmonary function, there was no significant difference between the non-air polluted area and air-polluted area, but there was found the slightly increase of air way resistance by oscillation technique in air polluted area.

3) Histopathological classification of chronic bronchopathy in childhood by bronchial biopsy was performed and was found that the chronic bronchitis was the epithelial cell denudation type. It was speculated that the recurrent air way infection in chronic bronchitis was based upon such histological finding.

4) An electron histochemical study of the adult rat and infant rat lung by $\mathrm{NO}_{2}$ gas inhalation was investigated. The results obtained that the different reactions were demonstrated in type II alveolar cells between adult rat and infant rat.

はじめに

大気污染の人体に及ぼす影響と呼吸器疾患と の関連性についてはすでに疫学調査をはじめ動 物実験による研究報告が多くみられる。

今回わたくしは東京都内の二地区小児に対し て呼吸器自覚症状調查とその一部に 1 秒率の検 索を行なった結果について報告し，ついで川崎 地区学童の呼吸抵抗值の検査成績について述べ る。また比較的長期間（6 カ月以上）湿性咳濑 が持続した小児の気管支生検について報告し， 併せて幼若成熟ラットに $\mathrm{NO}_{2}$ の高濃度曝露を 行ない，それによる肺胞 II 型細胞の反忘の差を 電顕的に検索した結果についても報告したい。

日本医科大学小児科学教室

\section{1. 東京都内二地区の学童調查}

東京都内において工場の多い下町の足立区の 学童及び中学生それぞれ 55, 513 名, 13, 265 名 と住宅地区の杉並区の学童及び中学生それぞれ 34, 265 名と 13, 998 名を対象としてアンケート 調查を行なった。なお小学生は両地区とも全学 年を対象としたが中学校生徒は杉並区は全学 年, 足立区は $1 ， 2$ 年のみを対象とした。

アンケートは文部省の B.M.R.C.に準じた調 査様式があるが, これは煩雑で家庭での記載に は不適当であり, 異なった環境で, どの家庭で る記載しやすいような簡単なアンケートを作製 した。このアンケートょり有症群を気管支炎症 状群, 慢性気管支炎症状群, 喘息様症状群, 喘 息症状群に一応分類することを試みた。 
表 1 アンケート調査結果

\begin{tabular}{|c|c|c|c|c|c|c|}
\hline & & $\begin{array}{l}\text { アンケート } \\
\text { 回 収 数 }\end{array}$ & 気管支炎症状 & 慢性気管支炎症状 & 喘息様症状 & 喘息 症 状 \\
\hline $\begin{array}{l}\text { 小 } \\
\text { 学 } \\
\text { 校 }\end{array}$ & $\begin{array}{l}\text { 杉並区 } \\
\text { 足立 区 }\end{array}$ & $\begin{array}{l}34295 \\
55513\end{array}$ & $\begin{array}{r}3,583(10.3) \\
10,364(18.7)\end{array}$ & $\begin{array}{r}571(1.7) \\
1,171(2.1)\end{array}$ & $\begin{array}{r}800(2.3) \\
3,232(5.8)\end{array}$ & $\begin{array}{r}851(2.5) \\
1,423(2.6)\end{array}$ \\
\hline $\begin{array}{l}\text { 中 } \\
\text { 学 } \\
\text { 校 }\end{array}$ & $\begin{array}{l}\text { 杉並 区 } \\
\text { 足立 区 }\end{array}$ & $\begin{array}{l}13998 \\
13265\end{array}$ & $\begin{array}{r}763(5.5) \\
1,201(9.0)\end{array}$ & $\begin{array}{l}111(0.8) \\
108(0.8)\end{array}$ & $\begin{array}{l}173(1.2) \\
388(2.9)\end{array}$ & $\begin{array}{l}183(1.3) \\
144(1.1)\end{array}$ \\
\hline
\end{tabular}

a. アンケート調査結果（表 1）

喘息と思われる症状（喘息症状群）を訴えた あのは両地区小中学校児童生徒ともその差は 0.1 0. $2 \%$ を示すのみで明瞭な差は認められな かった。これに対して喘息様症状を訴えるも の,すなわち喘鳴は訴えるが呼吸困難発作のな いものは足立区の小中学校児童生徒はそれぞれ $5.8 \% ， 2.9 \%$ で杉並区のそれは $2.3 \%$ と $1.2 \%$ であって両地区においては明らかな差がみられ 足立区学童生徒にこの訴えが多くみられた。気 管支炎症状群と慢性気管支炎症状群においても 後者の中学校生徒を除いて両地区においては喘 息様症状群と同様な傾向をしめした。

これでみると足立区は工場が多く，しかも国 道沿いの交通量の関係もあって杉並区に比して 大気污染地区とも考えられ，大気污染によって 足立区の小児は気管支炎や遷延慢性気管支炎及 び喘息様症状を呈するものが多いことが判明し た。しかし定型的な喘息と思われるものは両地 区とも差がみとめられなかった。本調查をもっ て直ちに有症児の素因やアレルギー関与につい て論ずることはできないが大気污染が訴え率や 有病率に関与していることが示唆された。これ とほほ同様なことは石岡の疫学的調査によって 報告されている゙。

これらの症状訴え率を小学生児童について学 年別にみると（図 1) 各症状とも有症率は第 1 学年が最高であって, 次第に減少し第 6 学年が 最低を示した。この傾向は両地区とも同様で, この減少傾向の程度は両地区之も気管支炎症状 群において著しかった。杉並区においてはその 他の症状群の訴え率の減少傾向は緩徐であり, 足立区では喘息様症状群の学年別減少カーブは 杉並区のそれに比して著しかった。両地区とも
症状訴え率は低学年より高学年になるに及んで その訴劣の減少はみられたが，学年別にみても 常に足立区が杉並区に比して高い值を示し，と くに気管支炎症状群と喘息様症状群において著 しかった。

b. スパイロメトリ一検査成績（䘚 2）

足立区小学校学童の 4 年生 2,270 名, 5 年生 2,089 名， 6 年生 2,054 名, 計 6,413 名と中学生 1 年生 1,180 名, 2 年生 1, 249 名, 計 2,424 名 に対してュニスパイロ $9 l$ のものを使用して肺 活量及び 1 秒率を测定した。

スパイロメーターはコンピューターに接続し 異常值をしめしたものは再度測定を行なって検 査方法の不理解や非協力による異常值を極力避 けるよ5にした。なお再度の测定で 1 秒率 $85 \%$ 未満を示したものは数週後に第 2 回目の検查を 再び同様な方法で実施した。ここでは 1 秒率に ついての成績を述べてみると小児の 1 秒率は正 常が $85 \%$ 以上又は $80 \%$ 以上といわれているが， 80\%以上を正常としてこれに満たないものを低

表 21 秒率低下例 (80\% 未満)

\begin{tabular}{|c|c|c|c|c|c|c|}
\hline & \multicolumn{2}{|c|}{ 第 1 回 } & \multicolumn{2}{|c|}{ 第 2 回 } & \multirow{2}{*}{$\begin{array}{l}\text { 両検査共 } \\
\text { 低 下例 }\end{array}$} \\
\hline & & 対象 & 低下例 & 対象* & 低下例 & \\
\hline 小 & 4 年 & 2270 & $\begin{array}{r}\% \\
33(1.5)\end{array}$ & 95 & $\begin{array}{r}\% \\
25(26.3)\end{array}$ & 6 \\
\hline \multirow{2}{*}{ 学 } & 5 & 2089 & $22(1.1)$ & 75 & $21(28.0)$ & 6 \\
\hline & 6 & 2054 & $25(1.2)$ & 74 & $12(16.2)$ & 5 \\
\hline 校 & 計 & 6413 & $80(1.2)$ & 244 & $58(23.8)$ & 17 \\
\hline \multirow{3}{*}{$\begin{array}{l}\text { 中 } \\
\text { 学 } \\
\text { 校 }\end{array}$} & 1 & 1180 & $12(1.0)$ & 24 & $7(29.3)$ & 3 \\
\hline & 2 & 1249 & $10(0.8)$ & 15 & $6(40.0)$ & 3 \\
\hline & 計 & 2439 & $22(0.9)$ & 39 & $13(33.3)$ & 6 \\
\hline
\end{tabular}

* 第 2 回検查対象は第 1 回検査で 1 秒率 $85 \%$ 未 満のもので第 2 回受診を希望せるもの 

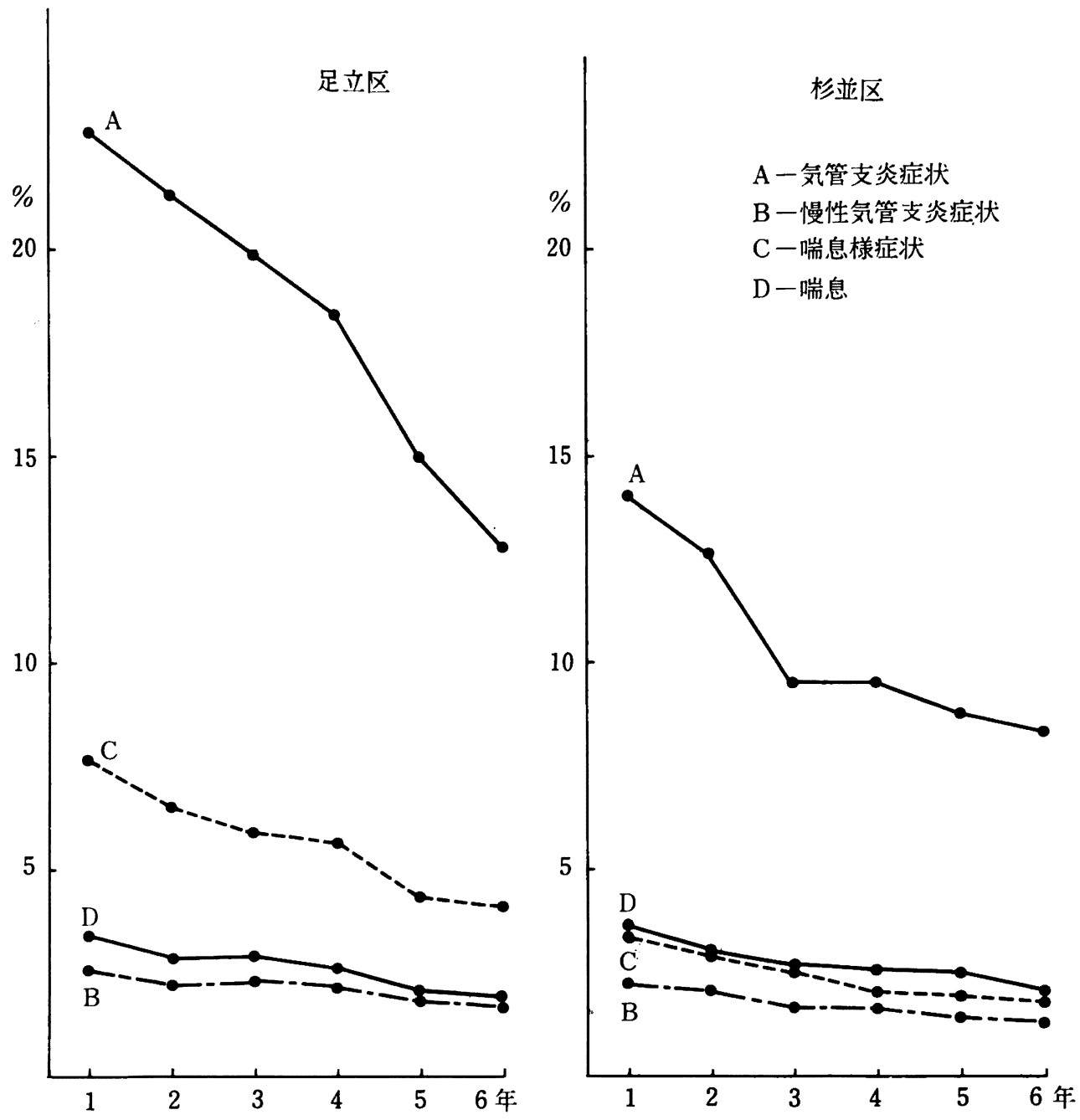

図 1 学年別症状群別訴え率

下例とすると小学校学童で $1.2 \%$ 中学校生徒で $0.9 \%$ であった。第 2 回検査では 1 秒率に $80 \%$ みたないものは小学校児童は $23.8 \%$ ありり, 中 学校生徒では33.3\%であった。なお第 1 , 第 2 回の両検査とも 1 秒率 $80 \%$ にみたないものは小 学校学童は 17 例 $0.3 \%$, 中学校生徒で 6 例 $0.2 \%$ であった。小児の 1 秒率を $85 \%$ 以上を正常と すると,これに満たないものは小学校学童で $4.0 \%$, 中学校生徒で $1.8 \%$ にるび, 第 1 , 第 2 回検査ともに $85 \%$ に満たないものは学童, 生 徒それそれ99例，1.5\%，10例，0.4\%であっ た。
第 1 回，第 2 回の検査で共に 1 秒率が $85 \%$ に 満たないものをアンケート上の自覚症状より分 析するとアンケートで全く自覚症状を訴えてな かったものは 109 例中 2 例のみで, 他の 107 例 は全て何らかの症状を訴えていた。とくに目立 ったことは既往に喘息，喘息様気管支炎あるい は気管支炎に罪患したが現在は呼吸器系自覚症 状を訴えていないもので1秒率の低下をしめし たものが 107 例中59例にも認められた。

足立区学童生徒についてみると呼吸器症状訴 え率に比較して肺機能低下（1秒率低下）を示 すものは少数であったが, 現在全く自覚症状を 
訴えないものでも過去に喘息や喘息様気管支炎 に罹患したすののなかに 1 秒率低下を示するの が䄪半数すみとめられたことは今後の経過追求 に一つの問題を提起した。

\section{2. 川崎地区学童の呼吸抵抗値について}

大気污染の気道系に及ぼす影響の一つとして 閉塞性障害をチェックするために 1 秒率の测定 が多く行なわれているが小児ではこの検査は effort dependent の問題もあるので教室の安田 は日本光電製 MRP-6 呼吸抵抗計を用いて川崎 市大気污染地区学童 1,215 名についてその呼吸 抵抗を測定した ${ }^{2)}$ 。なお小児の呼吸抵抗值の正 常值を求めるために群馬県農村小都市(富岡市) 学童 612 名を対照とした。

a. 呼吸抵抗予測式

呼吸抵抗值は男女児ともに身長との相関が最 も大であり，身長をすって呼吸抵抗值の予測式 を求めると次のごとくであった。

$$
\begin{gathered}
\text { 男児 }-0.025 x+6.8(2 \mathrm{SD}=0.59) \\
\text { 女坚 }-0.026 x+7.2(2 \mathrm{SD}=0.61) \\
\quad x \text { は身長, 単位 } \mathrm{cm} \mathrm{H}_{2} \mathrm{O} / \mathrm{L} / \mathrm{sec}
\end{gathered}
$$

b. 川崎市学童と富岡市学童との身長別呼吸 抵抗值の比較

呼吸抵抗值を両地区の学童で比較すると男児 では身長 $125 \sim 129 \mathrm{~cm}, 135 \sim 139 \mathrm{~cm}$ の群に, 女 児では身長 $115 \sim 119 \mathrm{~cm}$ と120 124cmの群にお いて川崎市学童の方が有意水準 $1 \%$ て呼吸抵抗 值は高值をしめした。また有意水準 $5 \%$ では女 児の身長 $135 \sim 139 \mathrm{~cm}$ 群においても川崎市学童 が高値を示していた。しかし予測值よりみると 両地区とも呼吸抵抗值の平均は正常範囲内にあ ったが川崎市学童の方がややその值は高い傾向 にあった。

c. 呼吸抵抗值增大例数の比較（表 3，4）

予測式よりの平均值 $\pm 2 \mathrm{SD}$ の範囲より高值 そ示す例数, すなわち呼吸抵抗增大例数を両地 区で比較すると男児では川崎地区 105 名（17.0 $\%)$, 富岡地区45名 (13.8\%), 女児では川崎地 区99例 (16.6\%), 富岡地区 43例 (15.1\%) で これらは $1 \%$ の危険率で有意差が認められ川崎 地区学童の方が呼吸抵抗增大を示すものが多い ことが認められた。
表 3 非污染地区および污染地区学童の呼 吸抵抗值增大例数の比較 (男児)

\begin{tabular}{c|r|r|r|r}
\hline & \multicolumn{2}{|c|}{ 富岡地区 } & \multicolumn{2}{c}{ 川崎地区 } \\
\hline 身 長 $(\mathrm{cm})$ & 例数 & \multicolumn{1}{c|}{$\%$} & 例数 & $\%$ \\
\hline $105 \sim 109$ & 0 & & 0 & \\
$110 \sim 114$ & 4 & 9.8 & 3 & 11.5 \\
$115 \sim 119$ & 6 & 13.0 & 10 & 13.8 \\
$120 \sim 124$ & 8 & 14.5 & 17 & 13.5 \\
$125 \sim 129$ & 10 & 15.9 & 23 & 17.0 \\
$130 \sim 134$ & 12 & 18.5 & 28 & 21.4 \\
$135 \sim 139$ & 3 & 9.7 & 2 & 19.8 \\
$140 \sim$ & $(2)$ & & $(2)$ & \\
\hline 計 & 45 & 13.8 & 105 & 17.0 \\
\hline
\end{tabular}

表 4 非污染地区扣よび污染地区学童の呼 吸抵抗值增大例数の比較 (女児)

\begin{tabular}{c|c|c|c|c}
\hline & \multicolumn{2}{|c|}{ 富岡地区 } & \multicolumn{2}{|c}{ 川崎地区 } \\
\hline 身 長 $(\mathrm{cm})$ & 例数 & $\%$ & 例数 & $\%$ \\
\hline $105 \sim 109$ & $(2)$ & & $(1)$ & \\
$110 \sim 114$ & 1 & 3.1 & 3 & 12.5 \\
$115 \sim 119$ & 5 & 11.4 & 9 & 15.3 \\
$120 \sim 124$ & 6 & 11.8 & 15 & 12.4 \\
$125 \sim 129$ & 11 & 19.6 & 27 & 19.0 \\
$130 \sim 134$ & 10 & 16.1 & 22 & 16.2 \\
$135 \sim 139$ & 6 & 15.4 & 18 & 19.6 \\
$140 \sim$ & $(2)$ & & $(4)$ & \\
\hline 計 & 43 & 15.1 & 99 & 16.6 \\
\hline
\end{tabular}

大気污染によってもたらされる気道疾患とし ての閉塞性呼吸器疾患を客観的にとら学指標 としての 1 秒率は effort dependent の問題があ り，小児でしかも mass の単位での検査では不 適ではないかと考えた。そこでオッシレーショ ン法による呼吸抵抗を測定し軽度な気道閉塞状 態を知ることができるのではないかと推測し検 索を行なったが川崎市（污染地区）学童の呼吸 抵抗值が明らかな高值を示すといら結果は得ら れなかった。しかし予測值よりみてその上限よ り逸脱する例数の比較では污染地区学童の方が より多数認められた。これのみをもって大気污 染の影響で川崎地区学童がある程度の気道閉塞 状態をきたしているとは言えないまです，少な くとも気道系に何らかの影響があることを示唆 している。 
大気污染による気道閉塞状態の発現にはかな り長期間あるいは反復的な曝露が必要であり, 時間的因子が重要であると考えられる。小児は 社会歴が短かく成長発育の factor b十分考虑 しなければならず，その5各個体の素因も症 状発現に大いに関係してくると思われる。

\section{3. 気管支生検所見}

小児の疾患は一般に急性に経過するものであ るといらことが通念であった。しかし近年小児 においても慢性疾患の增加がみられ呼吸器疾患 においても反復性慢性化の傾向がみられるよ5 になった。これらの原因として小児をとりまく 社会的環境の変化によることも一つの原因であ 万5と考兄られる。われわ机は小児において長 期間（6力月以上）の湿性咳嗽が持続するもの （小児慢性気管支炎）に対して経気管支鏡的に 気管支生検を行なっだ)。なお併せて比較検討 するために気管支喘息, 気管支拡張症について も気管支生検を行なった。

この組織学的所見を 5 つの型に分類した。

1) ciliated cell proliferative type, 線毛細 胞增殖型すなわち ciliated cell の增生を主と する型

2) mucin producing type, ムチン産生型, mucin を産生する goblet cell の增生を主とす る型

3) combind type 混合型 以上の 2 つの型 を混合する型

4) epithelial cell regenerating type 上皮細 胞再生型, 粘膜の再生を主とする型

5) epithelial cell denudation type 上皮細 胞剥離型, 粘膜上皮細胞の剥離を主とする型 この分類によると反復性慢性の咳嗽群では全例 （10例）が上皮細胞剥離型であった。また粘膜 下組織における細胞反応については気管支喘息 群 (3 例) では好酸球がやや多く認められ，小 児慢性気管支炎では㹩度の慢性疾患的の反応と してのリンハ球, 形質細胞が認められた。

\section{4. ウサギ, マウスの気管支の年齡的組蟣学 的变化}

小児の慢性気管支炎は大部分のものは約 2 年
間の経過で軽快治瘾していき成人のそれと異な るよ5である。大気污染地区学童の気道系障害 は成人のそれとやや相異があり，年齢的因子の 関与があると考兄られた。そこで年齢的因子の 解明のために動物を使用してその気管支壁の変 化を検索した。

この成績を総括的に述べるならば幼若期より 若齢期にかけてはその基本的な構造はほぼ同一 で, microvilli, cilia その他 ciliated cell およ び goblet cell の成熟は認められるが, 基底膜 の変化, 基底細胞における膠原線維の増生はほ とんどなく, 老齢期における変化と対照的であ った。

成人の慢性気管支炎といわれるものはその変 化は高度で不可逆的であり進行性の傾向がみら れ，小児のそれは軽度で可逆的であるようであ る。この差異は生体側の条件たとえば年齢的因 子にも，また環境側の侵襲の強さ，繁雑さ，侵 襲の期間の長さにもよると思われ，それぞれの 年令的基本的パターンの上に外的侵襲たと誉ば 大気污染, 細菌, ウイルスに対する生体反応に おいて質的なまた量的な差異が生ずることが予 測された。

\section{5. $\mathrm{NO}_{2}$ 曝露によるラット肺の年齢的差異}

大気污染の呼吸器への影響の年齢的差異を検 索するために今回はその予備的な実験として $\mathrm{NO}_{2}$ の高濃度約 $5 \mathrm{ppm}$ を 30 分間幼若ラット $(50 \mathrm{~g}, 5$ 羽) と成熟ラット $(200 \mathrm{~g}, 5$ 羽) に 曝露させて直後にその両群の肺組織を電顕的に 超微形態学的に観察を行なった。

幼若ラットの II 型細胞（写真 1) は成熟の II

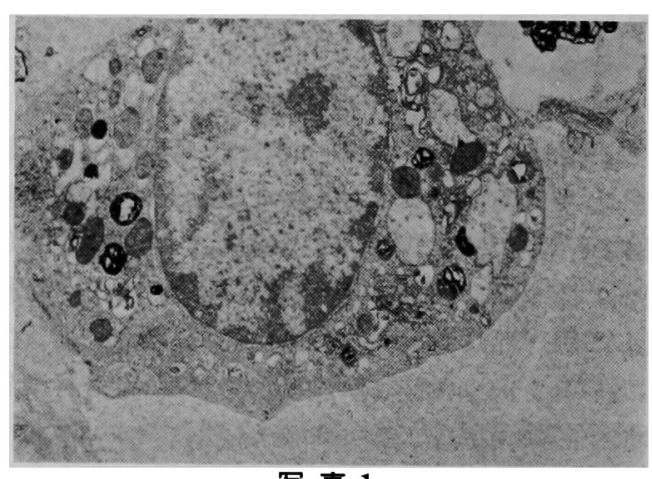

写 真 1 


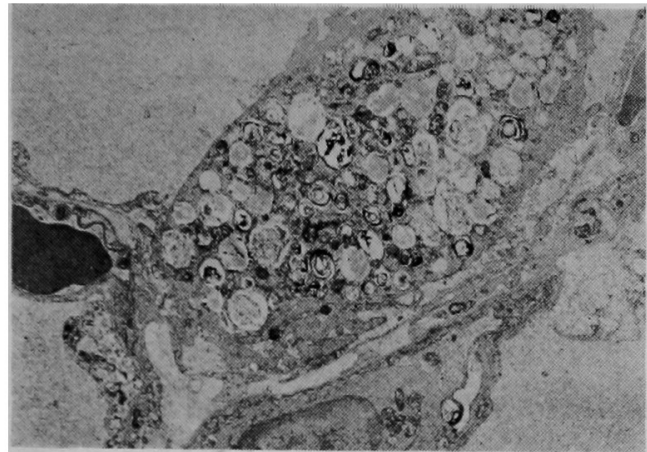

写 真 2

型細胞（写真 2) に比して肺 surfactant の産 生に関与していることが示唆されているいわゆ る層状封入体の数は少なく，ミトコンドリアな どの小器官の障害は軽度であった。更にムコ多 糖体の電顕的証明法として Ruthenium red 染 色法および燐脂質被覆層の証明法として tricomplex flocculation 法を行なったが, 幼若ラ ット, 成熟ラットでは肺胞型細胞の反応に有意 の差が認められた。しかし，これについては今 後更に詳細な検索を行ない, その解釈には慎重 でなければならない。

\section{今後の問題点}

1. 大気污染地区の学童は何らかのかたちで 気道系に侵襲を受けていることはアンケート調
査より明らかになった。しかしここれを呼吸機 能面から把握するためには，現在常用されてい る 1 秒率や呼吸抵抗值ではその変化が軽度で, かつ可逆性一過性であるため，また污染侵襲期 間が短かいために，これを検索するここはなか なか困難であり大気污染による呼吸障害を検出 するためのテクニックについて今後検討しなけ ればならない。またこれは小児に容易に応用し らるものでなければならない。

2. 大気污染の気道系への刺激作用として気 管支粘膜の浮腫, 気管支攣縮, 分泌物增加を招 来し, それに加えて感染防禦の低下, 感作準備 状態を来たすであろ5が，これらの反応は年齢 因子にも関係があり，この点についても今後追 求すべきであろう。

\section{文献}

1) 石西 伸：大気污染之呼吸器疾㭧, 疫学：特飞 北九州地区を中心として，日胸疾会誌 11 (12) 709,1973

2) 安田 正：小児の呼吸抵抗阔する研究, 第 1 編学童の呼吸抵抗とそれに及ほす大気污染の影響 そついて, 日医大誌 41 (6) 301，1974.

3 ) 後藤靖德：小児の慢性気管支炎の研究，第 2 編 気管支粘膜生検材料酒よる病理組織学的研究，日 医大誌 40 (5) 294，1973.

(別刷請求 : $=102$ 東京都千代田区飯田橋3-5-5 $\left(\begin{array}{c}\text { 日本医科大学付属第一病院小児科 } \\ \text { 豊 }\end{array}\right.$ 